\title{
Vegetation of Kalyana Karnataka Region, India
}

\author{
Rajasamarsen Modi $^{1, *}$, R S Kallurmath ${ }^{2}$, C. Haleshi $^{3}$, Shivakumar K ${ }^{4}$, Somanathareddy C. Patil ${ }^{5}$ \\ ${ }^{1}$ Department of Botany, Government College (Autonomous), Kalaburagi-585105, Karnataka, India \\ ${ }^{2}$ Government First Grade College for Women, Vijayapura- 586101, Karnataka, India \\ ${ }^{3}$ Department of PG Studies in Botany, Davangere University, Davanagere- 577007 Karnataka, India \\ ${ }^{4}$ Department of Chemistry, Government College (Autonomous), Kalaburagi-585105, Karnataka, India \\ ${ }^{5}$ Department of Zoology, Government College (Autonomous), Kalaburagi-585105, Karnataka, India
}

Received October 20, 2020; Revised November 30, 2020; Accepted December 20, 2020

\section{Cite This Paper in the following Citation Styles}

(a): [1] Rajasamarsen Modi, R S Kallurmath, C. Haleshi, Shivakumar K, Somanathareddy C. Patil , "Vegetation of Kalyana Karnataka Region, India," Advances in Zoology and Botany, Vol. 9, No. 1, pp. 8 - 15, 2021. DOI: 10.13189/azb.2021.090102.

(b): Rajasamarsen Modi, R S Kallurmath, C. Haleshi, Shivakumar K, Somanathareddy C. Patil (2021). Vegetation of Kalyana Karnataka Region, India. Advances in Zoology and Botany, 9(1), 8 - 15. DOI: 10.13189/azb.2021.090102.

Copyright $\bigcirc 2021$ by authors, all rights reserved. Authors agree that this article remains permanently open access under the terms of the Creative Commons Attribution License 4.0 International License

\begin{abstract}
Understanding the diversity of vegetation is a useful tool in plant ecology and forestry to compare the composition of different species. Kalyana Karnataka region is one of the largest arid regions in India. The natural vegetation can be seen mostly in the valleys and hill locks only. The forest vegetation generally falls under Southern tropical dry deciduous forest and Southern tropical thorn forests. Dry deciduous forests are found in small blocks almost throughout the area but the mere composition is at Chincholi in Kaluburagi district, Khanapur and Changler in Bidar District and Sandur and Sogi in Bellary. Trees of this region are generally drought resistant with wide distribution and have great adaptability (Anogeissus latifolia, Soymida febrifuga etc.). The occurrence of teak (Tectona grandis) in low to fair amount characterizes this type. Yadgir, Raichur and Koppal district comprising predominant thorny and hardwood species, main components are Acacia chundra, A. leucophloea, Albizia amara, Ixora arborea, Cassis fistula etc.; this can be classified as thorn forests. Associated and encountered shrubs and herbs in the region were also recorded. Interestingly, few insectivorous plants viz., Drosera indica, D. Burmanii, Utricularia species are found. Pteridophytes like Isoetes coramandaliana, Selaginella bryopteris, Pteris jeranifolia, Adiantum incisum etc. are creating botanical interest about the forest vegetation of Yadgiri and Raichur district.
\end{abstract}

Keywords Kalyana Karnataka, Forests, Vegetation

\section{Introduction}

Vegetation is an assemblage of plants growing under similar climatic conditions. The composition of vegetation depends on the assemblage of species population of a particular type and in turn the spatial distribution pattern of species population depends on the dispersal capacity of the species, the microclimatic condition in which it grows and other biotic factors Vegetation also play an important role in soil formation.

North-Eastern Karnataka is comprised of 6 districts of Karnataka state viz. Bidar, Kalaburagi, Yadgir, Raichur, Koppal, Bellary (Fig-1) as listed from north to South. Physiographically North-Eastern Karnataka falls in the 'Maidan' or the plain country and is mainly an inland plateau. The main features of plateau landscape are either flat or rolling, extensive plains between 300-900 m altitude. The peninsular plateau constitutes the largest physiographic division of India and consists of South Deccan plateau as one of its five sub-divisions, of which the Karnataka plateau is one of the constituents. There are some terrains in the southern part of the region (Singh, 1988). 


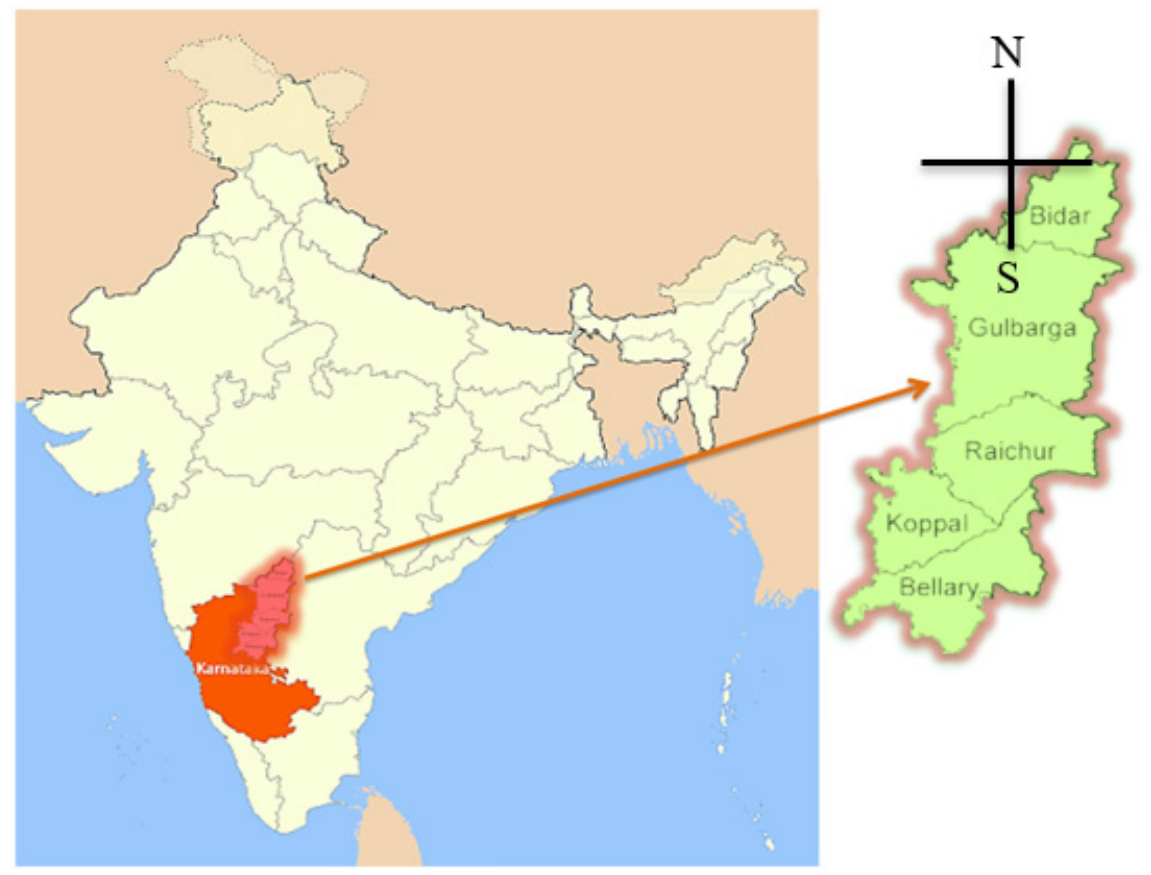

Figure 1. Map showing Districts of Kalyana Karnataka, India

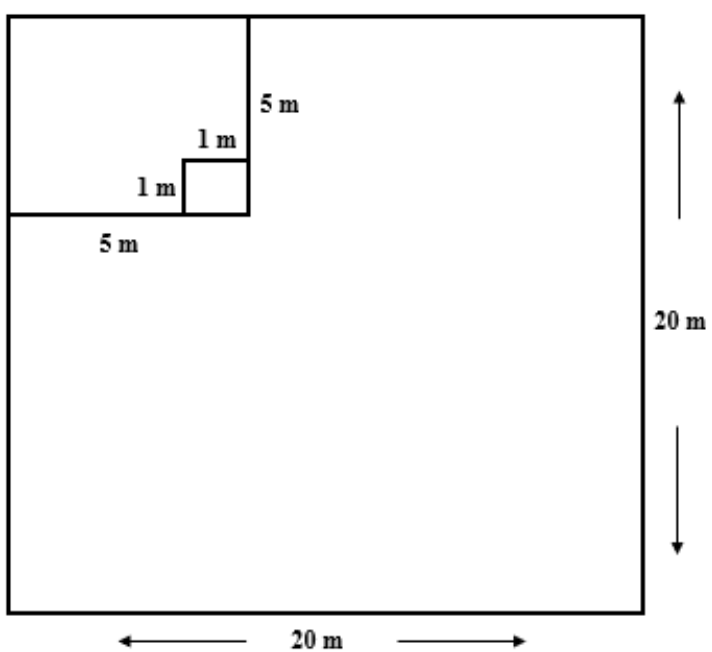

Figure 2. Quadrant laid at different places during the study

Geologically, this area varied from region to region, Bidar and Kalaburagi districts covered by dark coloured, large sheets of basic lava about 60 million years. A few of the economically important schist belts in the area are small bands of Kushtagi, Maski and Raichur. Small running bands of Sandur and copper mountain range and the Pennar-Hagari band in Ballari district. According to Raychaudhuri and Satyaprasad (1963) North-Eastern Karnataka has four types of soils. i) Laterite soils found in Southern Bidar and parts of Kalaburagi districts. ii) Red soil is found in almost all areas of the region except parts of Bidar and Kalaburagi districts. iii) Mixed red, yellow and grey soils are sedentary soils formed from the underlying, mostly granitic, parent rocks seen in parts of Raichur district and iv) Black soils are mainly found in the northern half besides on eastern and western boundaries of Ballari district.

The climate of North-Eastern Karnataka is generally dry, that can be classified as semi-arid. This area belongs to low rainfall area, receives rainfall from both South-West and North-East monsoon, South-West monsoon is responsible for maximum precipitation, and, the annual average rainfall is $668 \mathrm{~mm}$. The mean daily maximum temperature ranging from 25.3 to $29.7^{\circ} \mathrm{C}$ and daily minimum temperature ranging from 15.6 to $17.7^{\circ} \mathrm{C}$.

Ahmed, (2012) analysed the forest vegetation in Ranikhet, Kumaon Himalayas, Uttarakhand. Bhuyan et al., (2003) studied the tree diversity and population structure in undisturbed and human-impacted stands of tropical wet evergreen forest in Arunachal Pradesh, Eastern Himalayas, India. Tree species richness varied along the disturbance gradient in different stands. Kumar et al., (2006) studied the tree species diversity and distribution patterns in tropical forests of Garo Hills, Western Meghalaya, Northeast India. They found that the main vegetation of the region included primary secondary forest and Sal (Shorea robusta) plantations.

The structure of forest vegetation in India has been studied by several workers (Meher-Homji, 1973; Saxena and Singh, 1982; Singh and Singh, 1986). Singh and Singh (1987) have extensively reviewed studies on vegetation of the Himalaya including information on phytogeography, structure and functional aspects. Garga, (1988) have revealed the status of forests in India. Gaussen (1965) have worked maping of vegetation and environmental conditions of the world and in particular reference to India. 
Kharkwal and Rawat, (2010) studied the structure and composition of vegetation in sub-tropical forest of Kumaun, Himalaya. They found that Quercus leucotrichophora A. Campus, Quercus floribunda Lindl. ex Rehder, Quercus semecarpifolia J.E. Smith and Pinus roxburghii Sarg. were the dominant tree species in Banj-oak, Tilonj-oak, Kharsu-oak and Chir-pine forests respectively.

Some of the botanical exploration works have been attempted in the region by Singh (1988), Saldanha (1984), Gamble (1915-36) and Khan (1953). These workers have highlighted the areas in their works.

Considering the heterogeneity of forest landscapes, soils diversity vegetation structure and their ecological, economical and academic importance, no significant efforts have made by earlier researchers due to various reasons.

Detailed survey of vegetation will provide valuable information for forest assessment and improve our knowledge by the identification of ecologically, useful species as well as species of special concern, thus identifying conservation efforts for sustainability of riparian forest biodiversity. Hence, an attempt is made to provide comprehensive and unified account on vegetation of this region which in turns helpful for researchers, foresters, and students which are involved in the botanical studies.

\section{Methodology}

\section{Description of the Study Area}

The study was carried out in Kalyana-Karnataka region earlier it was known as Hyderabad Karnataka. The largest city of the the region is Kalaburagi falls in Latitude: $17^{\circ} 20^{\prime} 08^{\prime \prime} \mathrm{N}$ Longitude $76^{\circ} 50^{\prime} 15^{\prime \prime}$ and altitude ranges from 300 to $750 \mathrm{msl}$. Total area of the region is 44,138 $\mathrm{km}^{2}$ of which $1247.88 \mathrm{~km}^{2}$ area is of forest cover. The highest forest cover is in Bellary district $\left(739.22 \mathrm{~km}^{2}\right)$ and lowest in Koppal district $\left(88.42 \mathrm{~km}^{2}\right)$.
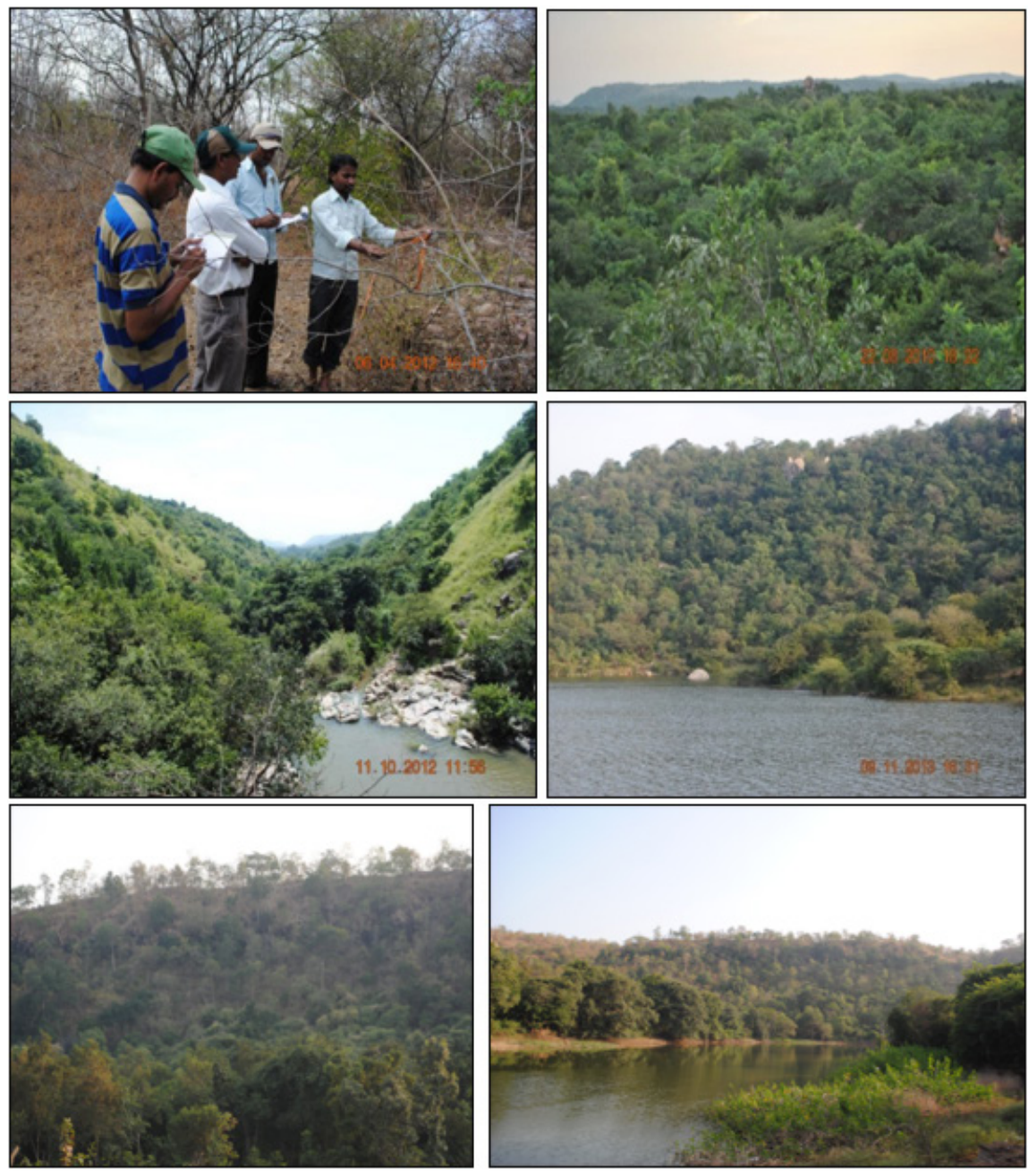

Figure 3. Panoramic view of different location of Forests of Kalyana Karnataka regions 
The most important factors determining the conditions of plant life in this region are attributed to low or scanty rainfall with long continuous drought period of six months besides high temperatures, especially during the summer seasons.

The region is endowed with diverse climate, topography and soils which has resulted in varied biodiversity. The diverse ecological niches support characteristic flora and fauna. The semi evergreen forests of the Sandur-Kumarswamy Hills cover about $60 \%$ of forest area of the region followed by Konchavaram forest of Chincholi taluk of Kalaburagi district (Chincholli Wildlife Sanctuary) (Fig-3).

Most of the areas of the region are subjected to different kinds of disturbances i.e., human induce or anthropogenic activities.

\section{Survey and Data Collection}

\section{Field Work and Sampling}

The survey had been planned in such a way to cover all the possible forest area of the region viz., Kalaburai Yadgir, Raichur, Bidar, Bellary and Koppal during all the seasons. A comprehensive and exhaustive data of the vegetation of the entire forest area was collected from 2014 to 2019.

Fidelibus and Mac Aller (1993) have agreed that in a study site quadrates can be established regularly, subjectively or randomly.

The floristic and physiognomic characteristics were studied and recorded during the said period. The structural physiognomy of each plant species encountered were grouped into broader classes based on their height and growth form viz., tree (woody plants taller than $1.5 \mathrm{~m}$ ), shrubs (woody plants from 0 to $1.5 \mathrm{~m}$ ), herbaceous and grasses.

A stratified random sampling approach was established. A squared field plot of size $20 \mathrm{~m} \times 20 \mathrm{~m}$ (Standardised Quadrat Sstructure) were inventoried. Each laid plot constitutes the tree species and their properties, i.e., canopy cover, density, and species composition etc. and sample plots were laid according to the recommendations of Gibbs Russell et al. (1985) (Plate-1). During the survey, most of the species were identified and recorded on site, if immediate identification was not possible, specimens were collected for later identification with keys.

\section{Identification of Plants}

The plants from the study sites were identified with the aid of regional floras (Hooker, 1897; Saldanha, 1984 \& 1996; Singh, 1988; Gamble and Fishcer 1935; Seetharam et al., 2000). In the taxonomical survey the rare plants are identified with the help of red data book and other literature surveys.

\section{Results and Discussions}

According to Champion and Set (1968) the vegetation of Northeastern Karnataka which is includes Hyderabad Karnataka (Now it is renamed as Kalyana Karnataka) province. The region comprises Bidar, Yadgir, Raichur, Koppal, Bellary and Kalaburagi that are in the present state of Karnataka and is the second largest arid region in India. Vegetation generally falls in to two regions viz., southern tropical dry deciduous forest and southern tropical thorn forest.

\section{Southern Tropical Dry Deciduous Forest}

The dry deciduous forests are found in small blocks almost throughout the area but to a much limited extent and the best ones are at Chincholi in Gulbarga district and Sandur and Sogi in Bellary districts. Trees here are generally drought resistant are of wide distribution and have great adaptability. Depending on the presence or absence of teak these forests can be classifiedas,

1. Very dry teak forests: The occurrence of teak in low to fair amount characterizes this type. These are open forests found at Chincholi of Kalaburagi, Sandur and Sogi of Bellary district and Changlera, Biranalli, Karakanalli of Bidar District. Tectona grandis is basic species of these forests.

Common Trees: The other characteristic tree species are Anogeissus latifolia, Boswellia serrrata, Terminalia alata, Sterculia urens, S.guttata, Givotia rottleriformis etc. Common trees are Chloroxylon swietenia, Dalbergia paniculata, D.latifolia, Pterocarpus marsupium, Wrightia tinctoria, Soymida febrifuga, Acacia leucophloea, Albezia lebbek, Bauhnia racemosa, Casssia fistula,Emblica officinalis, Polyalthia cerasoides, Butea monosperma, Steriospermum chelonoides, Syzygium cumini, Diospyros montana, Alangium salvifolium, Dolichnondrone falcata etc.

Common Shrubs: Flacourtia indica, Lantana camera, Cassia auriculata, Gymnsporia montana, Ziziphus nummularia, Carissa spinarum, etc. (occurring all types of habitat, especially in more open dry tracts). Canthium parviflorum, Diospyrous melanoxylon, D. chloroxylon, Gardenia gummifera, G. resinifera, Dodonea viscosa, Holarrhena antidysenterica, Triumfetta rhomboidea, Olax scandens, Helictres isora, Ximenia Americana, etc.

Common herbs: Lavandulla bipinnata, Pupalia lappacea, Vicoa indica and Tricholepis radicans are commonly distributed and frequently occurring herbs are Pavonia zeylanica, Euphorbia cristata, while Barleria cristata and Chlorophytum laxum, Andrographic paniculata occur occasionally. Among the grasses Apluda mutica, Heteropogon contortus, Chrysopogon aspera and Perotis indica are common one whereas Cymbopogan martini, Chrysopogon fulvus, Eragrostis tenella etc., occurs frequently. Cymbopogon coloratus is one of the 
dominant grass in the dry deciduous forests. Ephiphytic and ground orchids are rare found. Habenaria spp. found only in Chincholi Konchavaram and Sandur forest areas.

Climbers: Vines and climbers are the characteristics of dry deciduous forests, it constitutes up to $15 \%$ of the total species (Money et al., 1995). In Sandur, Karpakapalli and Konchavarum forests some of the common species like Ampelocissus tomentosa, Ipomoea muricata, I. obscura, I. pes-tigridis, I. eriocarpa, I. hederacea, Cryptolepis buchnani, Dioscorea oppsitifolia, Tetrastigma sulcatum, etc. but some species like Jasminum auriculatum, Combretum ovalifolium, Ventilago denticulate, Ipomoea staphylina are restricted in distribution and most common are Mucuna pruriens, Dioscorea tomentosa, D.pentaphylla while Celastrus paniculata is rare one.

2. Dry mixed deciduous forests: The vegetation distinguished by absence of teak predominance with xeromorphic species, Bamboos represented by Dendrocalamus strictus is found frequently in Yadgir district and Sandur, climbers are few while ephiphytes are absent and ferns are inconspicuous. Selaginella bryopteris occurs moderately and Actiniopteris radiata usually found under stone crevices.

Common Trees: Anogeissus latifolia is most common and found associated with Albizia amara, Terminalia alata, Chloroxylon swietenia, Hardwickia binata, Soymida febrifuga mixed with Accaia chundra, and Shorea roxburghii. Also found Pterolobium hexapetalum. General composition is similar to teak type, including shrubs, climbers, herbs and grasses.

\section{Southern Tropical Thorn Forests}

Widely scattered thorn forests in the present area are very open having thorny and hardwood species as its predominant and are generally short mixed with composed of thorn/prickly plants and are less in numbers. Such type of forests can be seen in Yadgir and Raichur district flora.

Common trees: Main components are Acacia chundra, A. leucophloea, A. latronum, Albizia amara, Ziziphus mauritiana, Cassis fistula found associated with Acacia nilotica. Ficus amplissima, F. mollis and Ziziphus xylorpyrus, Prosopis cineraria, Dolichondrone falcata, Hardwickia binata, Strychnos potatorum are occur occasionally.

Common Shrubs: Commonly occurring are Cadaba fruticosa, Canthium parviflorum, Dichrostachys cinerea, Maytenus emarginatus, Ixora arborea, Ziziphus oenoplia, Securinega lecusopyrus, Balanites aegyptiaca, Carissa spinarum, Tarenna asiatica, Toddalia asiatica and Pterolobium hexapetalum. Woodfordia fruticosa occur occasionly in Yadagir areas. Frequent ones are Capparis zeylanica, Calatropis gigantia, Cissus woodrowii, Ehretia laevis, Plumbago zeylanica, Kirganelia reticulata,
Capparis seperia, Capparis divericata, Opuntia dillenii, Ximenia americana. Barleria prionitis, Euphorbia antiqorum, Pavetta tomentosa, Capparis decidua occur occasionally.

Common herbs: The herbacius vegetation of the area are Dipterocanthus patulus, Echinops echinatus, Lavandulla bipinnata, Phyllanthus maderaspatansis, Waltheria americana, W. Indica, Aerva lanata (very common). Most common are Celosia argentea, Citrulus colocynthis, Merremia tridentata, Mollugo pentaphylla, Phyllanthus virgatus, Sophubia delpinifolia, Zornia gibbosa, Sesamum laciniatum, Chlorophytum acculare, Leucaas eiostoma, Pulicaria wightiana, Sesbania aegyptica. Those occasionally met with all over area Allmania nodiflora, Aniscohilus carnosus, Bleparis maderaspatensis, B.repens, Bidens bipinnata, Blumea obliqua, Glossoacrdia bosvallea, Lepidagathis cristata, Acalypha indica, Caralluma adscendens, Crotalaria retusa, C. medicaginea, C. pusila, Rungia repens etc. Aristida adscensionis, Chrysopogon fulvus and Dichanthium annulatum are the most common grasses.

Common Climbers: Climbers found in the area are quite distinct and characteristic some of the common ones are Cardiospermum helicabum, Coccinia grandis, Cocculus hirsutus, Gymnema sylvestre, Tylphora indica. Those frequently met with are Abrus precatorius, Corallocarpus epigaeus, Hemidesmus indicus, Derris scandens, Mukia maderaspatana, Leptadenia reticulata, Gloriosa superba, Passiflora foetida. Occasionally occurring are Argyreia cymosa, Asparagus racemosus and Dioscorea oppositifolia, Paracalyx scariosa, Dioscoria pentaphylla, Diplocyclos palmatus.

Common grasses: Apluda mutica, Heteropogon contortus Aristada setacea, Lophopogon tridentatus, Chrysopogon fulvus. Few species of Sehima occur rarely.

\section{Interesting Vegetation of the Yadgir Forest}

Few insectivorous plants have been observed keenly and took beautiful photographs of Drosera indica, Utricularia species. Soil seems to be is indication of less fertile and nitrogen deficient. Isoetes coramandaliana, Selaginella bryopteris (Sanjeevini) Pteridophytes are creating botanical interest about the forest.

\section{Conclusions}

Many studies confirmed that forests have an important role in maintaining the productivity of the environment; Plants serve as a standing cover to protect the land forms wind and water erosion, stabilizing the water cycle, facilitate the process of evaporation, and keep the soil porous.

Kalyan Karantaka (earlier name: Hyderabad Karnataka) enjoying with arid climate and most of the forests falls under the category of thorn scrubby jungles except few 
patches like Konchavaram, Chincholi, Changler, Sandur and Sogi are dry deciduous forests. Tectona grandis, Anageissus latifolia and Boswellia serrata are the basic component of the dry deciduous forests and fallowed by Chloroxylon swietenia, Dalbergia paniculata, Terminalia alata, Acacia chundra, Albizia amara, etc. Typical thorn scrubby jungles found in this area and represented by
Acacia chundra, Albizia amara, Wrightia tinctoria, Soymida febrifuga, Pterolobium hexapetalum, Ziziphus nummularia, Ziziphus oenoplia, Grewia flaescense, Acacia hohenackeri, Limonia acidissima, Mimosa hamata etc. Gyrocarpus americanus rarely seen in the rocky boulders of Yadgir district (Fig: 4 \& 5).
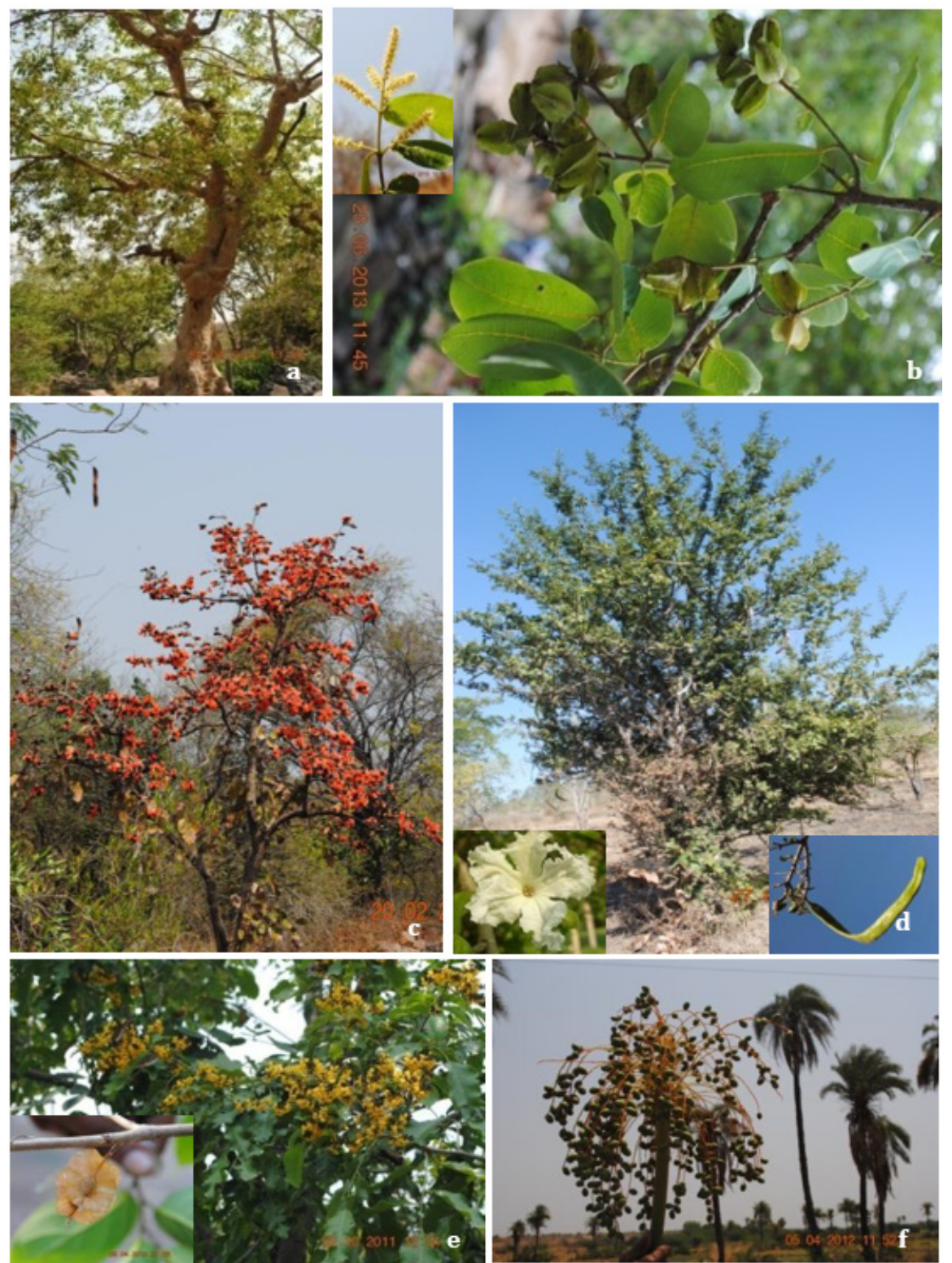

Figure 4. Selected Photographs of Tree species of Kalyana Karnataka Region, a. Terminalia arjuna (Roxb.) Wight \& Arn.; b. T. arjuna (Roxb.) Wight \& Arn. fruit and inflorescence; c. Aegle marmelos (L.) Correa.; d. Dolichondrone falcata Seem.; e. Butea monosperma (Lam.) Taub.; f. Pheonix dactylifera $\mathrm{L}$. 

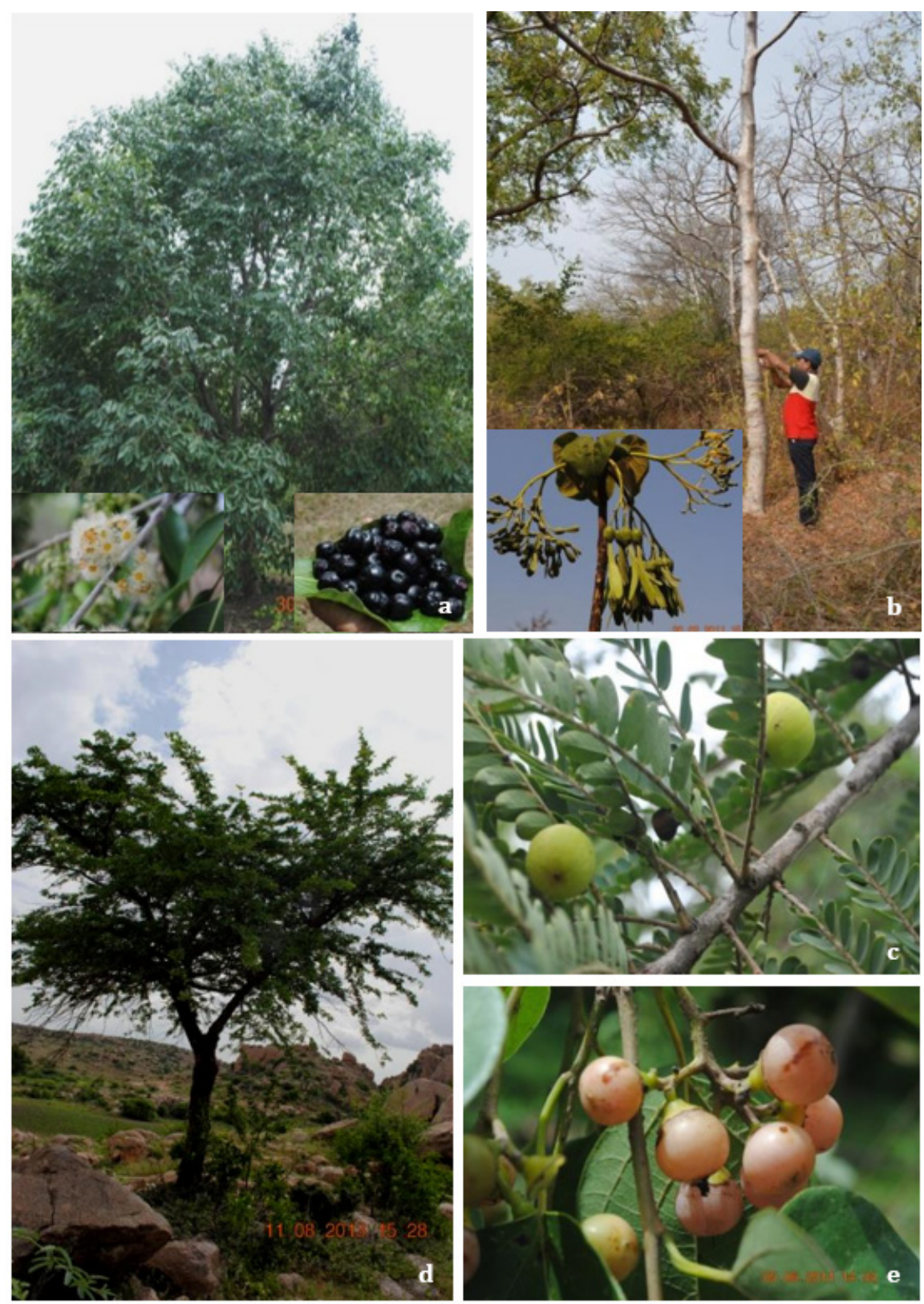

Figure 5. Selected Photographs of Tree species of Kalyana Karnataka Region, a. Syzygium cumini (L.) Skeels.; b. Gyrocarpus americanus Jacq.; c. Limonia acidissima L.; d. Phyllanthes emblica L.; e. Cordia dichotoma G. Forst

One of the most important factors determining the conditions of plant life in this region is low or scanty rainfall with long continuous drought period of more than six months besides high temperatures, especially during the summer seasons. These are supplemented by the prevalence of poor soils. The natural vegetation in the areas at present can be seen mostly on the hill locks only. The forest being open, allow a lot of scope for the invasion of fresh entrants.

These floristically rich forests shrinking like any other forests due to climatic and anthropogenic factors, the dry deciduous forests degraded to thorn scrubby jungles and to barren grass lands. Various factors threat to degrade the forests like fire is the regular occurrence, mining operations, illegal cuttings, collection of fire wood, encroachments, grazing etc. are main threats. Hence it needs immediate action to conserve the forest areas.

\section{Acknowledgements}

Authors are thankful to Late Dr. Y.N. Seetharam, Plant Taxonomist Department of PG Studies \& Research in Botany, Gulbarga University, Kalaburagi the guiding force. And we were also thankful to all the authorities of the Department of forests, Karnataka \& Karnataka Biodiversity Board, Bengaluru to carry out the survey in the forest by providing essential services and cooperation 
throughout the study and UGC for funding through Minor Project.

\section{REFERENCES}

[1] Ahmed, Ashfaque. Analysis of forest vegetation in Ranikhet, Kumaon Himalayas, Uttrakhand, India, Indian Journal of Fundamental and Applied Life Sciences, vol. 2, no. 4, pp. 16-23, 2012.

[2] P. Bhuyan, M. L. Khan, R. S. Tripathi, Tree diversity and population structure in undisturbed and human-impacted stands of tropical wet evergreen forest in Arunachal Pradesh, Eastern Himalayas, India, Biodiversity \& Conservation, vol. 12, no. 8, pp. 1753-1773, 2003.

[3] Champion, G. Harry, S. K. Seth. A revised survey of the forest types of India, Manager of publications, 1968.

[4] M. W. Fidelibus, R. T. F. Mac Aller. Restoration in the Colorado Desert: Management Notes, San Diego, California: California Department of Transport pp. 1-7, 1993.

[5] J. S. Gamble, C. E. C. Fishcer. Flora of the Presidency of Madras; Vol. I, II, and III. Botanical Survey of India, Calcutta, India. 1935.

[6] R. K. Garga. Status of Forests in India and Research needs, In: Environmental issues and researches in India. Himanshu publications, Udaipur, pp. 97-214, 1988.

[7] H. P. Gaussen, M. Legris, V. M. Viart, Meher-Homji, L. Labroue. International map of vegetation and environmental conditions, Sheet Mysore. Inst. Fr. Pondichéry. Trav. Sect. Sci. Tech. Hors Serie 7, 1965.
[8] C. Haleshi, Y. N. Seetharam, A.N. Sringeswara, M. D. Rajanna, G. Balakrishna. Life-form and biological spectrum of a dry deciduous forest at Sandur, Karnataka, My forest, vol. 41, no. 3, pp. 449-452, 2005.

[9] G. E. Gibbs Russel, C. Ried, J. Van Rooy, L. Smook. List of species of southern African plants, $2^{\text {nd }}$ edn, Part 1 . Mem. Bot. Surv, pp.1-152, 1985.

[10] J. .D. Hooker. The flora of British India, Vol. 1-7, Reeve, L." Co. Ltd. Ash ford, Kant, London, 1897.

[11] M. S. Khan. Forest Flora of Hyderabad State, Govt. Press, Hyderabad, 1953.

[12] Kumar, Ashish, G. Bruce, Marcot, Ajai Saxena. Tree species diversity and distribution patterns in tropical forests of Garo Hills, Current Science, pp. 1370-1381, 1988.

[13] Mooney, A. Harold, E. Medina, A. Gentry, H. S. H. Bullock. Diversity and floristic composition of neotropical dry forests. Seasonally dry tropical forests. No. 581.5264 S439. Cambridge University Press, pp 221-239. 1995.

[14] Y. N. Seetharam, C. Haleshi. Assessment of plant biodiversity of dry deciduous forest of Sandur, Karnataka, Ecol. Env. and Cons, vol. 5, no. 1, pp. 1-6, 1999.

[15] Y. N. Seetharam, K. Kotresh, S. B. Uplaonkar. Flora of Gulbarga district, Gulbarga University, Gulbarga, 2000.

[16] Raychaudhuri, Satya Prasad. Soils of India, Indian Council of Agricultural Research, 1963.

[17] J. S. Singh, S. P. Singh. Forest vegetation of the Himalaya. The Botanical Review, vol. 53, no. 1, pp. 80-192, 1987.

[18] N. P. Singh. Flora of Eastern Karnataka, Vol. 1 \& 2. Mittal Publications, 1988. 